\title{
Non-medical use of baclofen: A case series and review of the literature
}

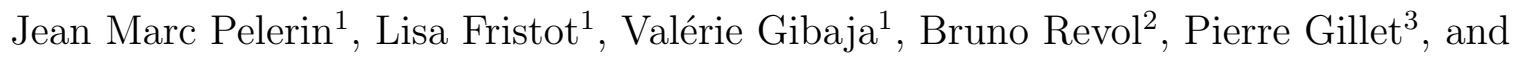 \\ Juliana Lima-Tournebize ${ }^{1}$ \\ ${ }^{1} \mathrm{CHRU}$ de Nancy \\ ${ }^{2}$ Centre Hospitalier Universitaire Grenoble Alpes \\ ${ }^{3}$ University Hospital of Nancy
}

July 12,2021

\begin{abstract}
Aims: Baclofen is widely used for spastic disorders, and most recently for addictive disorders. The first signals of baclofen abuse occurred in the last decade. This study aims to assess the motives, diversion sources and routes of administration associated with the non-medical use of baclofen and examine health problems related to the non-medical use of baclofen. Methods: Spontaneous reports of baclofen abuse reported to the addictovigilance center of East France were analyzed. A literature search was simultaneously conducted using PubMed@, Web of Sciencesß, and Google Scholarß databases. Both searches were performed in February 2021 without a time limit. Results: Forty-six cases were analysed (33-from the literature review and 13-from addictovigilance base). Baclofen's non-medical use mainly affected male subjects with addictive history, but cases of primary abuse in subjects without any substance abuse history were also observed. Euphoria search was the most common reason for misuse. Route of administration included oral, snorting and sublingual use. Physicians were a common source for misused baclofen, but cases involving illegal sources were also observed. Most of the patients misusing baclofen presented serious complications, mainly represented by neurological and respiratory disturbances. Physical and psychological dependence to baclofen was observed in three persons. Conclusion: Although baclofen abuse remains relatively infrequent or (most likely) underestimated, this study helped to confirm the intrinsic abuse potential of baclofen and make visible the baclofen-abuse-related health harms. Careful consideration and benefit-risk analysis should be employed when prescribing baclofen, and emergency departments should be aware of baclofen dangers in abuse situations.
\end{abstract}

\section{Hosted file}

Main text.docx available at https://authorea.com/users/425196/articles/530069-non-medicaluse-of-baclofen-a-case-series-and-review-of-the-literature 
5
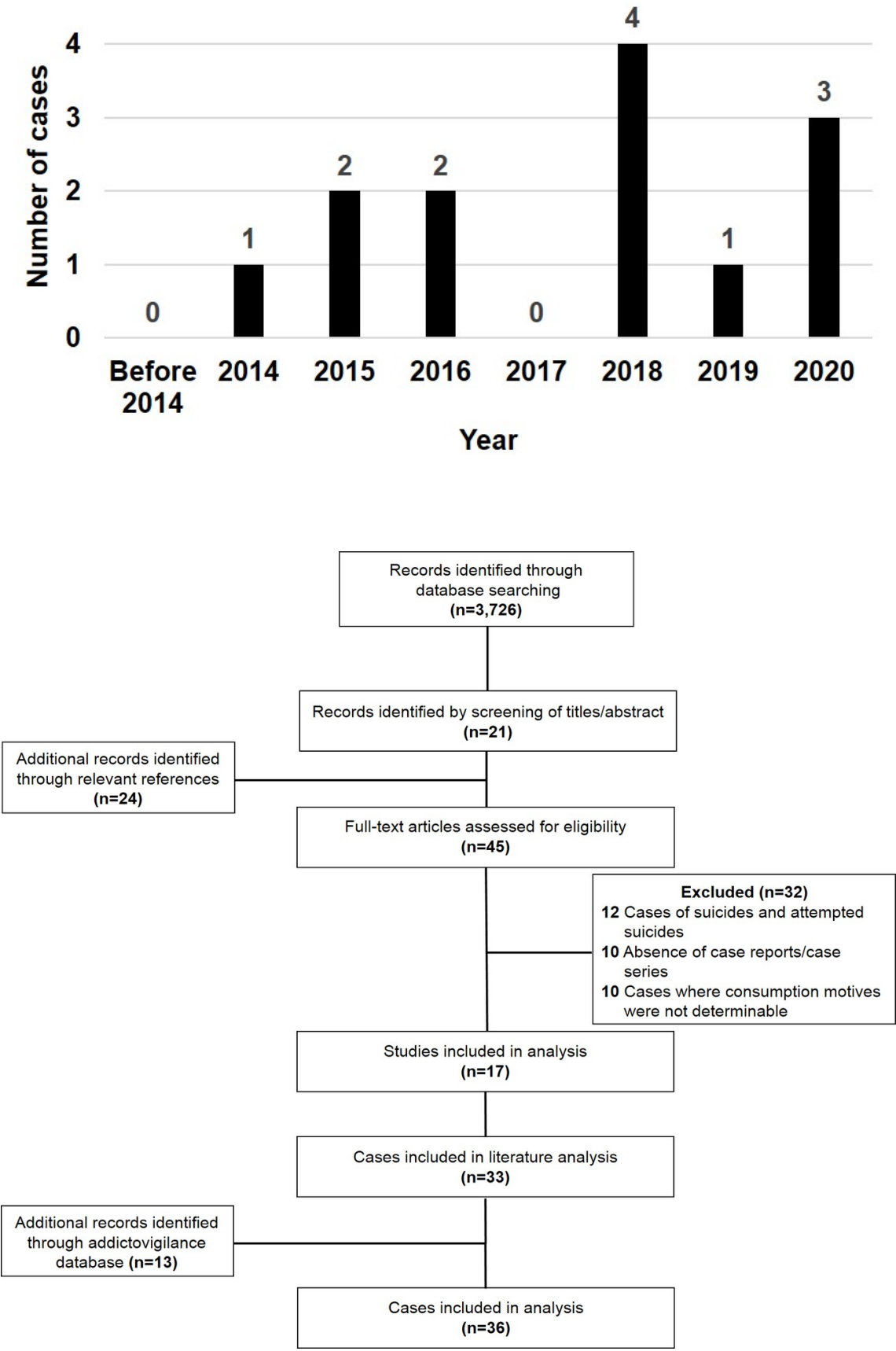


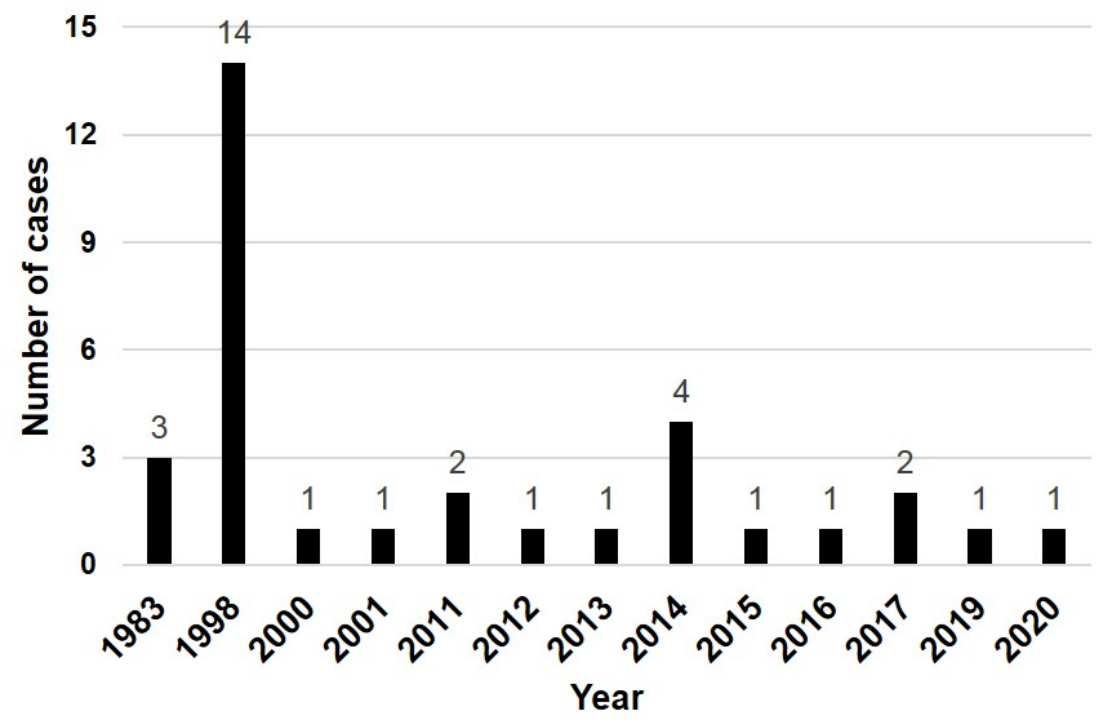

\section{Hosted file}

Table 1.docx available at https://authorea.com/users/425196/articles/530069-non-medical-useof-baclofen-a-case-series-and-review-of-the-literature

\section{Hosted file}

Table 2.docx available at https://authorea.com/users/425196/articles/530069-non-medical-useof-baclofen-a-case-series-and-review-of-the-literature 